IP Periodica Polytechnica Chemical Engineering

\author{
62(3), pp. 299-304, 2018 \\ https://doi.org/10.3311/PPch.11459 \\ Creative Commons Attribution (i)
}

RESEARCH ARTICLE

\section{High Loaded Synthetic Hazardous Wastewater Treatment Using Lab- Scale Submerged Ceramic Membrane Bioreactor}

\author{
Mashallah Rezakazemi $^{1 *}$, Mohsen Maghami², Toraj Mohammadi
}

Received 07 September 2017; accepted after revision 08 November 2017

\begin{abstract}
Submerged ceramic membrane bioreactors (SCMBRs) are more efficient combinations of traditional activated hazardous sludge and new membrane separation processes in wastewater treatment. Suspended solids are separated from hazardous effluent using microfilter ceramic membranes in SCMBRs. A high loaded wastewater was treated using an SCMBR employing a homemade tubular ceramic membrane in laboratory scale. Hydraulic Retention Time (HRT) was $32 \mathrm{~h}$ and COD range was varied from 2000 to $5000 \mathrm{mg} / \mathrm{l}$. COD removal was evaluated to be more than $90 \%$ after a week and the lab scale SCMBR showed desired performance for the wastewater treatment. Mixed Liquor Suspended Solid (MLSS) was increased from 2000 to $4000 \mathrm{mg} / \mathrm{L}$ during the SCMBR operation time.
\end{abstract}

\section{Keywords}

membrane, wastewater, hazardous, submerged, activated sludge

\footnotetext{
${ }^{1}$ Department of Chemical Engineering,

Shahrood University of Technology, Shahrood, Iran

${ }^{2}$ Research and Technology Centre for Membrane Processes,

Faculty of Chemical Engineering, Iran University of Science and Technology (IUST), Narmak, Tehran, Iran
}

*Corresponding author, e-mail: mashalah.rezakazemi@gmail.com

\section{Introduction}

Wastewater management and development of new processes to treat different wastewaters have found considerable attentions to save the environment and supply growing requests on water [1-4]. Membrane separation processes have come to represent key technologies when closing water loop systems and recycling materials are employed in manufacturing processes [5-7]. Thus, membrane technology has established itself and proven its effectiveness as a cost-effective and ecological alternative to other separation methods $[8,9]$ such as gas separation [10-13], pervaporation [14, 15], evaporation, adsorption and absorption, chemical separation or distillation [16-18]. High purification potential of membrane separation processes makes it possible to meet the requirements applicable to advanced wastewater treatment for protection of water and groundwater resources [19-21]. Membrane pressure driven processes are subdivided into microfiltration (MF), ultrafiltration (UF), nanofiltration (NF), forward osmosis (FO), and reverse osmosis (RO) according to size or molecular mass of the separable substances [22]. Combination of UF or MF with activated sludge called membrane bioreactor (MBR) for wastewater treatment is an effective process which can be used for municipal and industrial wastewaters [23-25]. Ceramic microporous membranes have been used for this propose because of their advantages like good chemical stability, favorable mechanical strength, stability at high temperatures, good antimicrobial ability, and high separation efficiency [26]. These membranes could be made from alumina, mullite, cordierite, silica, spinel, zirconia and other refractory oxides. Ceramic membrane bioreactors have been used for wastewater treatment in the food industry, purification of alkaline cleaning solutions in the dairy industry, and clarification and purification of drinking water [27-30]. These purification and/or treatment result in reusing wastewaters and/or extending usage period before discharging them and hence saving the environment, energy, water, and chemicals [31]. As ceramic MBRs can remove bacteria and clarify water in a single step process, it is possible to reduce appreciably the classic sequences of water/wastewater treatment processes. More applications of industrial wastewater 
treatment were also reported [32-34]. Many parameters affecting the MBR performance like solid retention time (SRT), the behavior of the accumulated Soluble Microbial Product (SMP), aeration (nutrition and membrane fouling reduction), were studied by other researchers. The aim of this research was to characterize an SCMBR in terms of COD reduction at high organic loading rate and variable biomass concentration.

\section{Materials and methods}

\subsection{Membrane preparation}

Mullite microfilters were prepared from micronized kaolin clay, dedicated by Iran China Clay Industries Company with composition reported in Table 1. Kaolin clay was suspended in distilled water using Stuart stirrer (SS20) and the suspension was filtered using a 270 mesh sieve (Damavand test sieves Ltd., particle size $<53 \mu \mathrm{m}$ ). The suspension was then allowed to be settled inside its container and the upper clear water was removed periodically. Finally, a homogeneous mud was obtained and tubularly extrudates were extruded. For uniform drying and avoiding mechanical stress when tubes were dried, the wet extrudates were placed inside an oven at $100{ }^{\circ} \mathrm{C}$ for a few hours. After that, the dried extrudates were placed inside a furnace (Zohouri Furnace Industries) to be sintered with a heating rate of $2{ }^{\circ} \mathrm{C} / \mathrm{min}$ at $1225^{\circ} \mathrm{C}$ for $3 \mathrm{~h}$. Finally, ceramic tubular membranes of $9 \mathrm{~mm}$ ID, $14 \mathrm{~mm}$ OD and $25 \mathrm{~cm}$ length were obtained. The sintered membranes were characterized with XRD and mercury porosimetry, as shown in Figs. 1 and 2.

Free silica was removed from the sintered membranes by leaching with $20 \mathrm{wt} . \%$ aqueous caustic soda solution at $80^{\circ} \mathrm{C}$ for $5 \mathrm{~h}$. Removal of the free silica results formation of in microporous tubular ceramic membranes with high porosity. After washing with the aqueous caustic soda solution, membranes were washed with distilled water for $12 \mathrm{~h}$ at $80^{\circ} \mathrm{C}$ in order to remove the caustic soda.

\subsection{SCMBR set up}

A schematic diagram of a laboratory scale experimental system is shown in Fig. 3. The set up consisted of aerated bioreactor with working volume of $10 \mathrm{~L}$ and a dispensing pump transferring feed from the feed tank to the aerated bioreactor. Three ceramic microfilters (ID $=9 \mathrm{~mm}, \mathrm{OD}=14 \mathrm{~mm}$, Length $=25 \mathrm{~cm}$ ) were connected to a collector where a plastic tube connected the collector to the permeate tank. The permeate tank was vacuumed employing a vacuum pump (BCV vacuum pumps, $\mathrm{P} 2-\mathrm{S}$ ). Vacuum pressure was indicated using an analog pressure gauge. A pH meter (Lab-215, palintest Inc.) and a dissolved oxygen (DO) probe ( $\mathrm{HACH}$, Germany) were also installed in the SCMBR to monitor $\mathrm{pH}$ and $\mathrm{DO}$ online. SCMBR operation temperature and steady-state continuous flow rate were held at $32{ }^{\circ} \mathrm{C}$ and $3 \mathrm{~mL} / \mathrm{min}$ (resulting in hydraulic retention time (HRT) of $32 \mathrm{~h}$ ), respectively. Other operational parameters are given in Table 2.
Table 1 Kaolin (named SZWNL1) composition as reported by the manufacturer, Iran China Clay Industries Company

\begin{tabular}{|c|c|}
\hline Component Name & Weight Percent (\%) \\
\hline $\mathrm{SiO}_{2}$ & 63.63 \\
\hline $\mathrm{Al}_{2} \mathrm{O}_{3}$ & 24.05 \\
\hline $\mathrm{Fe}_{2} \mathrm{O}_{3}$ & 0.65 \\
\hline $\mathrm{TiO}_{2}$ & 0.04 \\
\hline $\mathrm{CaO}$ & 1.40 \\
\hline $\mathrm{MgO}$ & 0.50 \\
\hline $\mathrm{Na}_{2} \mathrm{O}$ & 0.30 \\
\hline $\mathrm{K}_{2} \mathrm{O}$ & 0.20 \\
\hline L.O.I & 9.22 \\
\hline
\end{tabular}

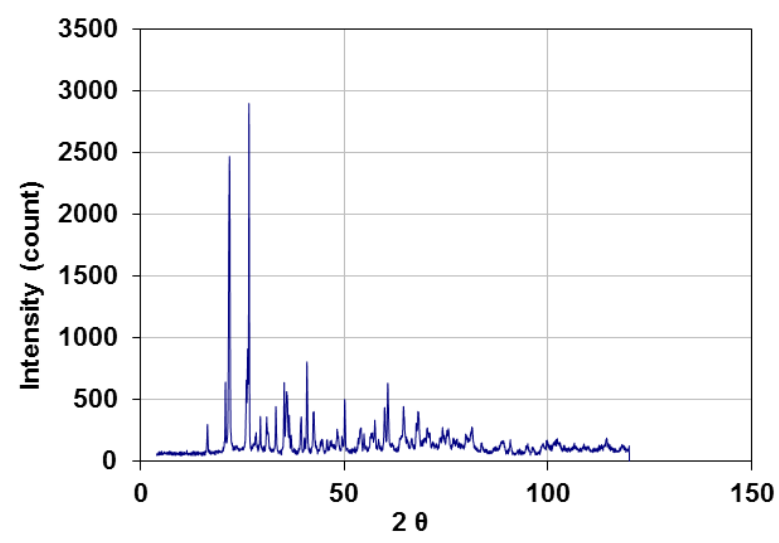

Fig. 1 XRD pattern of the sintered membrane at $1225^{\circ} \mathrm{C}$ for $3 \mathrm{~h}$, major phases are Mullite $\left(\mathrm{Al}_{6} \mathrm{Si}_{2} \mathrm{O}_{13}\right)$, Cristobalite $\left(\mathrm{SiO}_{2}\right)$ and Quartz $\left(\mathrm{SiO}_{2}\right)$, minor phase is Calcite $\left(\mathrm{CaCO}_{3}\right)$.

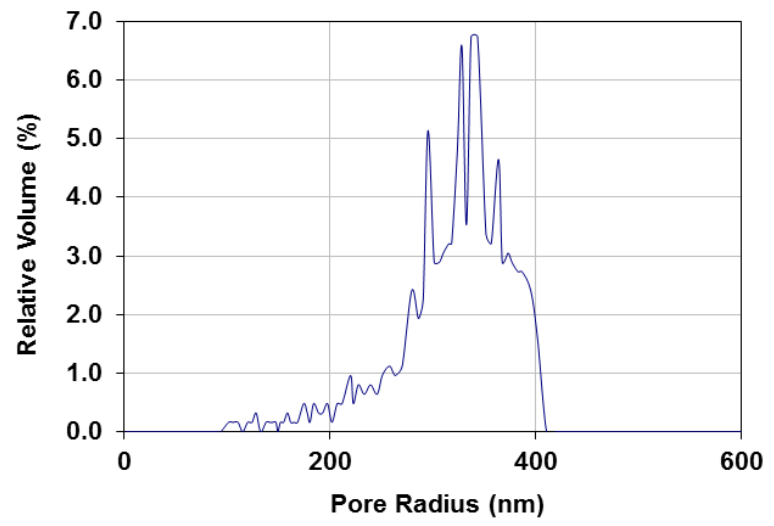

Fig. 2 Pore radius distribution of the sintered membrane at $1225^{\circ} \mathrm{C}$.

Table 2 SCMBR operational parameters

\begin{tabular}{ll}
\hline Properties & Value \\
\hline HRT $(\mathrm{h})$ & 32 \\
SRT (day) & $\infty$ \\
DO (mg/L) & $4-5$ \\
Air flowrate $(\mathrm{L} / \mathrm{min})$ & 4 \\
Temperature $\left({ }^{\circ} \mathrm{C}\right)$ & $32 \pm 1$ \\
$\mathrm{pH}$ & $7 \pm 0.5$ \\
\hline
\end{tabular}




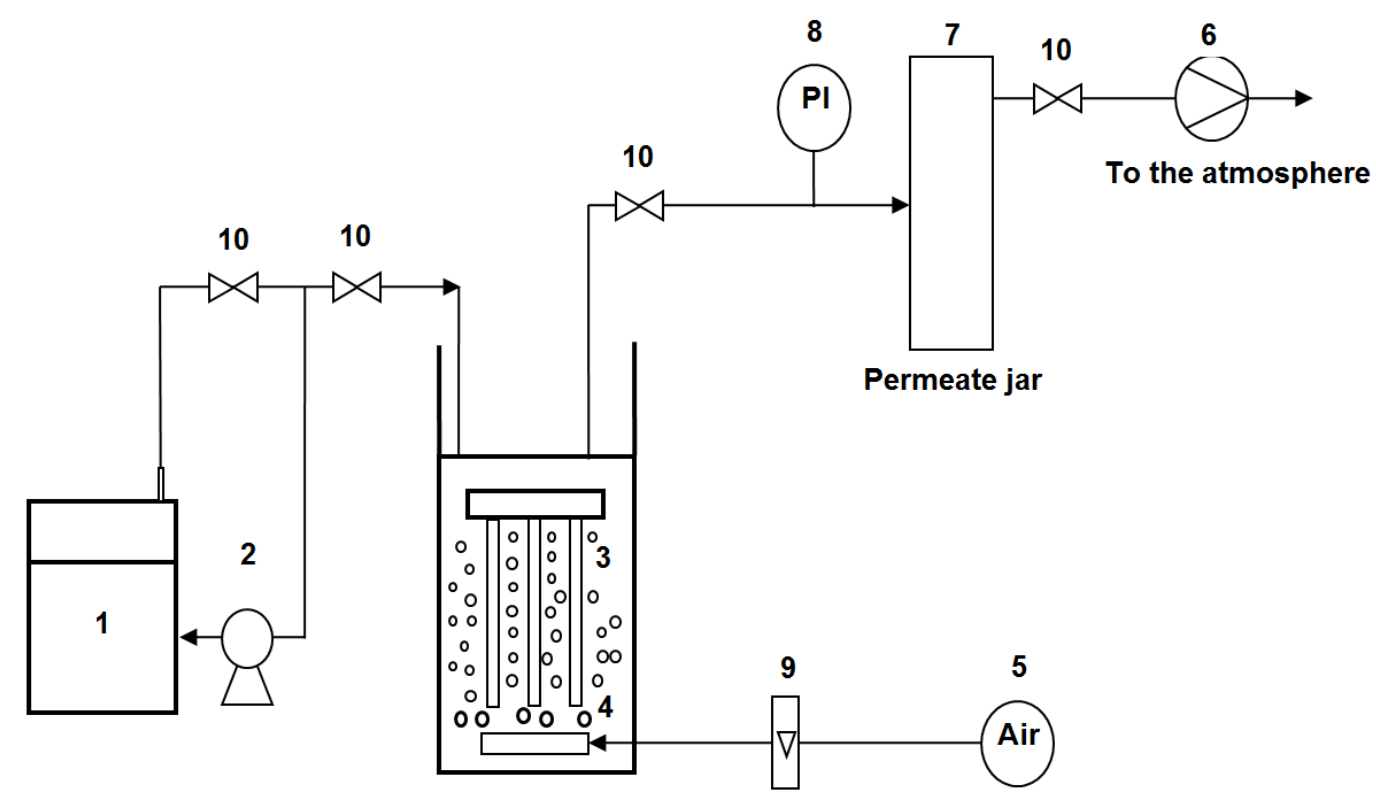

Fig. 3 A schematic drawing of the SCMBR. 1: feed tank, 2: feed pump, 3: ceramic membrane module, 4: air diffuser, 5: air pump, 6: vacuum pump, 7: permeate tank, 8: pressure indicator, 9: air flow meter, and 10: valve.

\subsection{Synthetic influent}

Activated sludge used was supplied from Tehran refinery with initial Mixed MLSS of $2000 \mathrm{mg} / \mathrm{L}$. The SCMBR was operated for 25 days while the activated sludge was fed with glucose continuously to reach MLSS to more than $4000 \mathrm{mg} / \mathrm{L}$. Under aeration condition, DO was kept around 4-5 mg/L. Glucose, $\left(\mathrm{NH}_{4}\right)_{2} \mathrm{SO}_{4}$, and $\mathrm{KH}_{2} \mathrm{PO}_{4}$ were used as source of carbon, nitrogen and phosphorous respectively, making COD:N:P to be 100:5:1. COD of the feed was changed in the range of $2000-5000 \mathrm{mg} / \mathrm{L}$. Table 3 shows the synthetic wastewater components. The range of COD was selected based on some investigated industrial wastewaters with COD concentrations more than $2000 \mathrm{mg} / \mathrm{L}$. These high COD loadings have high risks of discharging to the environment and should be treated before discharging. Landfill and dairy wastewaters are high COD loading wastewaters. As a result, the synthetic wastewater was selected with a composition close to these industries.

Table 3 Constituents of the synthetic wastewater

\begin{tabular}{ll}
\hline Compounds & Values $(\mathrm{mg} / \mathrm{l})$ \\
\hline Glucose $\left(\mathrm{C}_{6} \mathrm{H}_{12} \mathrm{O}_{6}\right)$ & $2000-5000$ \\
Ammonium sulfate $\left(\left(\mathrm{NH}_{4}\right)_{3} \mathrm{SO}_{4}\right)$ & $100-250$ \\
Potassium phosphate $\left(\mathrm{KH}_{2} \mathrm{PO}_{4}\right)$ & $20-50$ \\
Calcium chloride $\left(\mathrm{CaCl}_{2} \cdot{ }_{2} \mathrm{H}_{2} \mathrm{O}\right)$ & $2.45-6.1$ \\
Magnesium sulfate $\left(\mathrm{MgSO}_{4} \cdot 7 \mathrm{H}_{2} \mathrm{O}\right)$ & $33-82.5$ \\
Manganese chloride $\left(\mathrm{MnCl}_{2} \cdot 4 \mathrm{H}_{2} \mathrm{O}\right)$ & $1.85-4.5$ \\
Zinc sulfate $\left(\mathrm{ZnSO} \cdot 7 \mathrm{H}_{2} \mathrm{O}\right)$ & $2.8-6.5$ \\
Ferric chloride anhydrous $\left(\mathrm{FeCl}_{3}\right)$ & $8.6-20$ \\
Cupric sulfate $\left(\mathrm{CuSO}_{4} \cdot 5 \mathrm{H}_{2} \mathrm{O}\right)$ & $3-6$ \\
Cobalt chloride $\left(\mathrm{CoCl}_{2} \cdot 6 \mathrm{H}_{2} \mathrm{O}\right)$ & $3-7$ \\
Sodium molybdate dehydrate $\left(\mathrm{Na}_{2} \mathrm{MoO}_{4} \cdot 2 \mathrm{H}_{2} \mathrm{O}\right)$ & $8-20$ \\
Yeast extract & 300 \\
\hline
\end{tabular}

\subsection{Analytical methods}

COD and MLSS were measured according to the procedures described in Standard Methods. COD was measured by spectrometry (Palintest, England). For measuring MLSS, three samples were taken each time and the average value was reported.

\section{Results and discussion}

\subsection{Flux decline phenomenon}

Fig. 4 shows flux decline of the ceramic membranes under constant vacuum pressure during $2 \mathrm{~h}$. As observed, increasing transmembrane pressure (TMP) leads to higher membrane flux due to higher driving force, however, increasing TMP results in sharper initial flux decline due to the more membrane pore blockage and the membranes surface fouling. As observed, the membrane flux decline can be divided into two stages, a sharp decay stage and a pseudo-steady state stage. As observed, for a TMP of 0.2 bar, initial sharp decay is not the case indicating there is no serious membrane pore blockage and membrane surface fouling can be removed by means of aeration. In the case of other studied TMPs, at the early period of filtration, the flux reduces sharply due to the rapid membrane pore blockage and the significant biomass and dust deposition. In these cases, aeration is not sufficient to keep the flux constant and flux decline occurs due to surface fouling and pore blockage. Flux decline rates of fluxes, become much slower after $20 \mathrm{~min}$. In fact, the fluxes approach to their pseudo-steady stage values. Steady state flux of the SCMBR at $32{ }^{\circ} \mathrm{C}$ and with MLSS of $2500 \mathrm{mg} / \mathrm{L}$ was compared with that of distilled water at different TMPs, as shown in Fig. 5. It can be seen that by increasing TMP from 0.2 to 0.4 bar, distilled water flux changes from 6 to $12 \mathrm{~L} / \mathrm{m}^{2} \mathrm{~h}$, while steady state flux of the SCMBR varies in the range of 4 to $5 \mathrm{~L} / \mathrm{m}^{2} \mathrm{~h}$ showing the fact that pore blockage in the SCMBR reduces the flux and increasing 


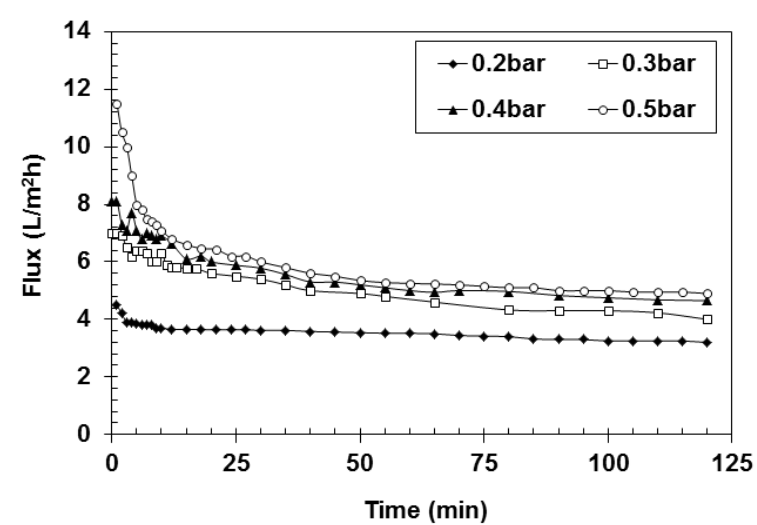

Fig. 4 Permeation flux decline of the ceramic membranes (MLSS of $2500 \mathrm{mg} / 1$ at $32{ }^{\circ} \mathrm{C}$ ).

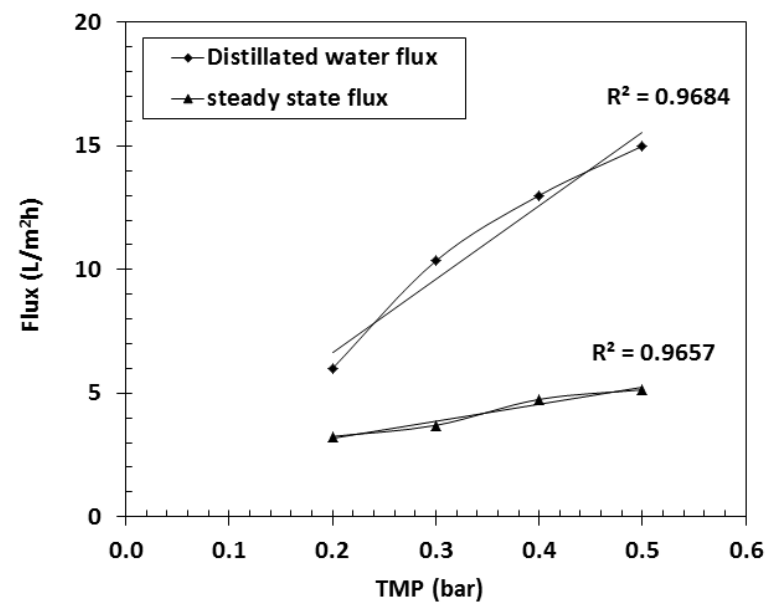

Fig. 5 Effect of TMP on steady-state flux (MLSzS of $2500 \mathrm{mg} / 1$ at $32{ }^{\circ} \mathrm{C}$ ) and distilled water flux.

TMP cannot recover it totally. Generally, it can be mentioned that permeation flux of submerged membranes which is lower than $30 \mathrm{l} / \mathrm{m}^{2} \mathrm{~h}[35,36]$ is lower than that of external membranes in a cross-flow mode which is upper than $301 / \mathrm{m}^{2} \mathrm{~h}[37,38]$.

\subsection{Steady state flux and MLSS growth during SCMBR operation}

The SCMBR was operated without any chemical cleaning during the experimental period. As mentioned above, steady state flux of the ceramic membranes was kept constant at $4-5 \mathrm{~L} / \mathrm{m}^{2} \mathrm{~h}$ by means of TMP adjustment resulting in HRT of $32 \mathrm{~h}$ during the experiment. Unlike the adjusted flux, the membrane permeability was reduced because of the membrane pore blocking caused in the operation period. Increasing TMP in order to keep the flux constant, results in more the membrane surface fouling and the membrane pore blockage and this causes the membrane permeability to decrease within the experimental period. The flux and permeability of the SCMBR is shown in Fig. 6. Due to the feed loading in the range of 0.4-1 (kg COD/kg MLSS. day), MLSS was increased from 2000 to $4000 \mathrm{mg} / \mathrm{L}$. MLSS growth in the SCMBR during the experimental period is shown in Fig. 7.

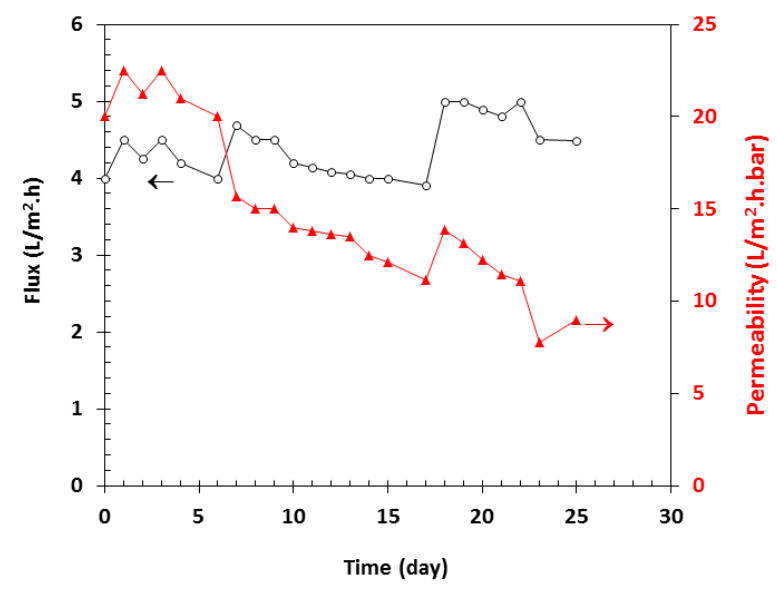

Fig. 6 Steady state flux and permeability of the ceramic membranes during the SCMBR operational period.

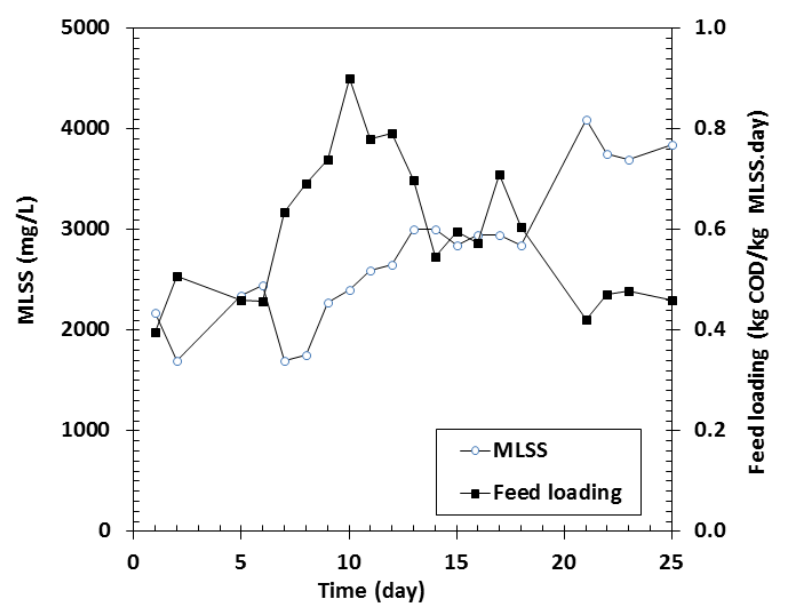

Fig. 7 MLSS growth during the SCMBR operation.

\subsection{COD removal}

Organic removal in the SCMBR was very high and stable during the operational period. The effluent COD of the SCMBR was varied in the range of $0-250 \mathrm{mg} / \mathrm{L}$, and the average value is around $100 \mathrm{mg} / \mathrm{L}$. The influent and effluent COD values illustrated in Fig. 8. The influent COD fluctuated from 2000 to $5000 \mathrm{mg} / \mathrm{L}$; however, the effluent COD was maintained at a low and steady level. Taking 25 days of the experiment, an averaged COD removal efficiency of $95 \%$ was achieved after 4 days. After that, the effluent COD was not influenced by the influent COD variation.

\section{Conclusions}

Application of homemade ceramic microfilters in an SCMBR was investigated. The results showed that no significant flux decline is observed at low TMP, however increasing TMP results in significant reduction of the membrane permeability. The results also showed that the ceramic membranes have high potential for separation of treated water from activated sludge in the SCMBR. The designed SCMBR exhibited 95\% COD removal during 4 days, while MLSS was increased from 2000 to $4000 \mathrm{mg} / \mathrm{L}$. 


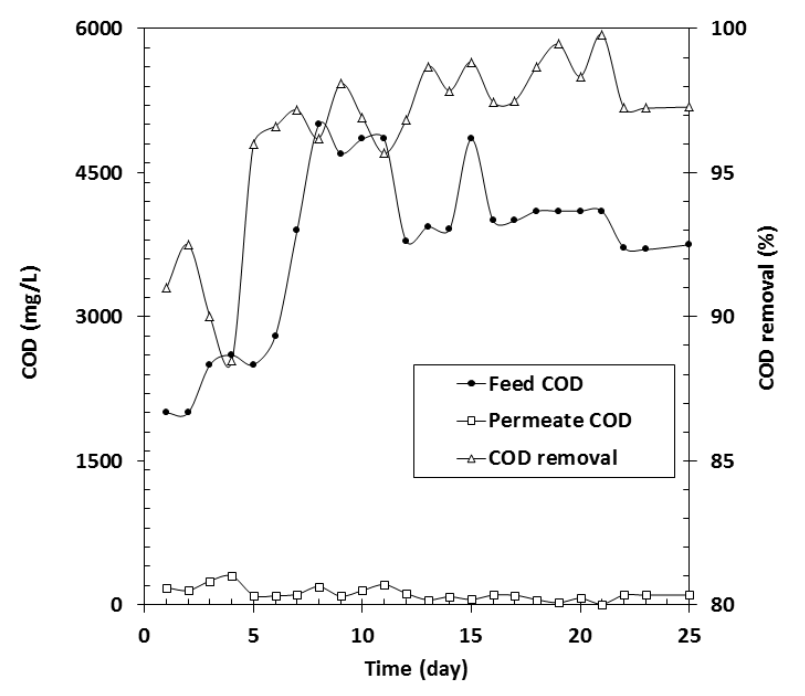

Fig. 8 Feed and permeate COD and COD removal during the SCMBR operational period.

The SCMBR was found to perform desired properties of significant COD removal with high permeation flux.

\section{References}

[1] Azimi, A., Azari, A., Rezakazemi, M., Ansarpour, M. "Removal of Heavy Metals from Industrial Wastewaters: A Review." ChemBioEng Reviews. 4(1), pp. 37-59. 2017. https://doi.org/10.1002/cben.201600010

[2] Foroutan, R., Esmaeili, H., Abbasi, M., Rezakazemi, M., Mesbah, M. "Adsorption behavior of $\mathrm{Cu}(\mathrm{II})$ and $\mathrm{Co}(\mathrm{II})$ using chemically modified marine algae." Environmental Technology. pp. 1-9. 2017. https://doi.org/10.1080/09593330.2017.1365946

[3] Rezakazemi, M., Shahverdi, M., Shirazian, S., Mohammadi, T., Pak, A. "CFD simulation of water removal from water/ethylene glycol mixtures by pervaporation." Chemical Engineering Journal. 168(1), pp. 60-67. 2011. https://doi.org/10.1016/j.cej.2010.12.034

[4] Muhammad, A., Younas, M., Rezakazemi, M. "Quasi-dynamic modeling of dispersion-free extraction of aroma compounds using hollow fiber membrane contactor. Chemical Engineering Research and Design. 127(Supplement C), pp. 52-61. 2017. https://doi.org/10.1016/j.cherd.2017.09.007

[5] Shirazian, S., Rezakazemi, M., Marjani, A., Moradi, S. "Hydrodynamics and mass transfer simulation of wastewater treatment in membrane reactors." Desalination. 286, pp. 290-295. 2012.

https://doi.org/10.1016/j.desal.2011.11.039

[6] Rezakazemi, M., Ghafarinazari, A., Shirazian, S., Khoshsima, A. "Numerical modeling and optimization of wastewater treatment using porous polymeric membranes." Polymer Engineering and Science. 53(6), pp. 1272-1278. 2013.

https://doi.org/10.1002/pen.23375

[7] Rezakazemi, M., Shirazian, S., Ashrafizadeh, S.N. "Simulation of ammonia removal from industrial wastewater streams by means of a hollow-fiber membrane contactor." Desalination. 285, pp. 383-392. 2012. https://doi.org/10.1016/j.desal.2011.10.030

[8] Rezakazemi, M., Shahidi, K., Mohammadi, T. "Synthetic PDMS composite membranes for pervaporation dehydration of ethanol." Desalination and Water Treatment. 54(6), pp. 1542-1549. 2015.

https://doi.org/10.1080/19443994.2014.887036
[9] Rezakazemi, M., Niazi, Z., Mirfendereski, M., Shirazian, S., Mohammadi, T., Pak, A. "CFD simulation of natural gas sweetening in a gas-liquid hollow-fiber membrane contactor." Chemical Engineering Journal. 168(3), pp. 1217-1226. 2011.

https://doi.org/10.1016/j.cej.2011.02.019

[10] Sadrzadeh, M., Rezakazemi, M., Mohammadi, T. "Fundamentals and measurement techniques for gas transport in polymers." In: Thomas, S., Wilson, R., S., A. K., Geroge, S. C. (eds.) Transport Properties of Polymeric Membranes. (pp. 391-423). Elsevier. 2017. https://doi.org/10.1016/B978-0-12-809884-4.00019-7

[11] Farno, E., Rezakazemi, M., Mohammadi, T., Kasiri, N. Ternary gas permeation through synthesized pdms membranes: Experimental and CFD simulation basedon sorption-dependent system using neural network model." Polymer Engineering and Science. 54(1), pp. 215-226. 2014. https://doi.org/10.1002/pen.23555

[12] Rezakazemi, M., Mohammadi, T. "Gas sorption in $\mathrm{H}_{2}$-selective mixed matrix membranes: Experimental and neural network modeling." International Journal of Hydrogen Energy. 38(32), pp. 14035-14041. 2013. https://doi.org/10.1016/j.ijhydene.2013.08.062

[13] Rezakazemi, M., Vatani, A., Mohammadi, T. "Synthesis and gas transport properties of crosslinked poly(dimethylsiloxane) nanocomposite membranes using octatrimethylsiloxy POSS nanoparticles." Journal of Natural Gas Science and Engineering. 30, pp. 10-18. 2016. https://doi.org/10.1016/j.jngse.2016.01.033

[14] Rezakazemi, M., Sadrzadeh, M., Mohammadi, T. "Separation via pervaporation techniques through polymer membranes." In: Thomas, S., Wilson, R., S., A. K., Geroge, S. C. (eds.) Transport Properties of Polymeric Membranes. (pp. 243-263). Elsevier. 2017. https://doi.org/10.1016/B978-0-12-809884-4.00013-6

[15] Rezakazemi, M., Iravaninia, M., Shirazian, S., Mohammadi, T. "Transient Computational Fluid Dynamics (CFD) Modeling of Pervaporation Separation of Aromatic/Aliphatic Hydrocarbon Mixtures Using Polymer Composite Membrane." Polymer Engineering and Science. 53(7), pp. 1494-1501. 2013. https://doi.org/10.1002/pen.23410

[16] Rezakazemi, M., Heydari, I., Zhang, Z. "Hybrid systems: Combining membrane and absorption technologies leads to more efficient acid gases $\left(\mathrm{CO}_{2}\right.$ and $\left.\mathrm{H}_{2} \mathrm{~S}\right)$ removal from natural gas." Journal of CO2 Utilization. 18, pp. 362-369. 2017.

https://doi.org/10.1016/j.jcou.2017.02.006

[17] Rezakazemi, M., Ebadi Amooghin, A., Montazer-Rahmati, M.M., Ismail, A.F., Matsuura, T. "State-of-the-art membrane based $\mathrm{CO}_{2}$ separation using mixed matrix membranes (MMMs): An overview on current status and future directions." Progress in Polymer Science. 39(5), pp. 817-861. 2014.

https://doi.org/10.1016/j.progpolymsci.2014.01.003

[18] Rezakazemi, M., Razavi, S., Mohammadi, T., Nazari, A.G. "Simulation and determination of optimum conditions of pervaporative dehydration of isopropanol process using synthesized PVA-APTEOS/TEOS nanocomposite membranes by means of expert systems." Journal of Membrane Science. 379(1-2), pp. 224-232. 2011. https://doi.org/10.1016/j.memsci.2011.05.070

[19] Aslam, M., Charfi, A., Lesage, G., Heran, M., Kim, J. "Membrane bioreactors for wastewater treatment: A review of mechanical cleaning by scouring agents to control membrane fouling." Chemical Engineering Journal. 307, pp. 897-913. 2017. https://doi.org/10.1016/j.cej.2016.08.144

[20] Deng, L., Guo, W., Ngo, H.H., Zhang, H., Wang, J., Li, J., Xia, S., Wu, Y. "Biofouling and control approaches in membrane bioreactors." Bioresource Technology. 221, pp. 656-665. 2016.

https://doi.org/10.1016/j.biortech.2016.09.105 
[21] Wang, Z., Ma, J., Tang, C.Y., Kimura, K., Wang, Q., Han, X. "Membrane cleaning in membrane bioreactors: A review." Journal of Membrane Science. 468, pp. 276-307. 2014.

https://doi.org/10.1016/j.memsci.2014.05.060

[22] Judd, S., Judd, C. "Chapter 2 - Fundamentals."In: Judd, S., Judd, C (eds.) The MBR Book. (pp. 55-207.) 2nd edition, Butterworth-Heinemann, Oxford. 2011.

https://doi.org/10.1016/B978-0-08-096682-3.10002-2

[23] Skouteris, G., Hermosilla, D., López, P., Negro, C., Blanco, Á. "Anaerobic membrane bioreactors for wastewater treatment: A review." Chemical Engineering Journal. 198, pp. 138-148. 2012. https://doi.org/10.1016/j.cej.2012.05.070

[24] Huang, L., Lee, D.-J. "Membrane bioreactor: A mini review on recent R\&D works." Bioresource Technology. 194, pp. 383-388. 2015. https://doi.org/10.1016/j.biortech.2015.07.013

[25] Mutamim, N. S. A., Noor, Z. Z., Hassan, M. A. A., Yuniarto, A., Olsson, G. "Membrane bioreactor: Applications and limitations in treating high strength industrial wastewater." Chemical Engineering Journal. 225, pp. 109-119. 2013. https://doi.org/10.1016/j.cej.2013.02.131

[26] Rezakazemi, M., Mirzaei, S., Asghari, M., Ivakpour, J. "Aluminum Oxide Nanoparticles for Highly Efficient Asphaltene Separation from Crude Oil Using Ceramic Membrane Technology." Oil \& Gas Science and Technology. 72(6), pp. 1-9. 2017. https://doi.org/10.2516/ogst/2017031

[27] Shirazian, S., Rezakazemi, M., Marjani, A., Rafivahid, M. S. "Development of a mass transfer model for simulation of sulfur dioxide removal in ceramic membrane contactors." Asia-Pacific Journal of Chemical Engineering. 7(6), pp. 828-834. 2012. https://doi.org/10.1002/apj.641

[28] Das, B., Chakrabarty, B., Barkakati, P. "Preparation and characterization of novel ceramic membranes for micro-filtration applications." Ceramics International. 42(13), pp. 14326-14333. 2016. https://doi.org/10.1016/j.ceramint.2016.06.125

[29] Malzbender, J. "Mechanical aspects of ceramic membrane materials." Ceramics International. 42(7), pp. 7899-7911. 2016. https://doi.org/10.1016/j.ceramint.2016.02.136
[30] Fasihi, M., Shirazian, S., Marjani, A., Rezakazemi, M. "Computational fluid dynamics simulation of transport phenomena in ceramic membranes for $\mathrm{SO}_{2}$ separation." Mathematical and Computer Modelling. 56(11-12), pp. 278-286. 2012.

https://doi.org/10.1016/j.mcm.2012.01.010

[31] Agoudjil, N., Benmouhoub, N., Larbot, A. "Synthesis and characterization of inorganic membranes and applications." Desalination, 184(1-3), pp. 65-69. 2005.

https://doi.org/10.1016/j.desal.2005.04.034

[32] Meng, F., Chae, S.-R., Drews, A., Kraume, M., Shin, H.-S., Yang, F., "Recent advances in membrane bioreactors (MBRs): Membrane fouling and membrane material." Water Research, 43(6), pp. 1489-1512. 2009. https://doi.org/10.1016/j.watres.2008.12.044

[33] Low, S. L., Ong, S. L., Ng, H. Y. "Characterization of membrane fouling in submerged ceramic membrane photobioreactors fed with effluent from membrane bioreactors." Chemical Engineering Journal. 290, pp. 91-102. 2016. https://doi.org/10.1016/j.cej.2016.01.005

[34] Jin, L., Ong, S. L., Ng, H. Y. "Fouling control mechanism by suspended biofilm carriers addition in submerged ceramic membrane bioreactors."Journal of Membrane Science. 427, pp. 250-258. 2013. https://doi.org/10.1016/j.memsci.2012.09.016

[35] Psoch, C., Schiewer, S. "Long-term study of an intermittent air sparged MBR for synthetic wastewater treatment." Journal of Membrane Science. 260(1-2), pp. 56-65. 2005. https://doi.org/10.1016/j.memsci.2005.03.021

[36] Low, S. C., Juan, H. H., Siong, L. K. "A combined VSEP and membrane bioreactor system." Desalination. 183(1-3), pp. 353-362. 2005. https://doi.org/10.1016/j.desal.2005.04.028

[37] Xu, N., Xing, W., Xu, N., Shi, J. "Study on ceramic membrane bioreactor with turbulence promoter." Separation and Purification Technology. 32(1-3), pp. 403-410. 2003. https://doi.org/10.1016/s1383-5866(03)00073-x

[38] Rahman, M. M., Al-Malack, M. H. "Performance of a crossflow membrane bioreactor (CF-MBR) when treating refinery wastewater." Desalination. 191(1-3), pp. 16-26. 2006.

https://doi.org/10.1016/j.desal.2005.05.022 